\title{
GENERALIZED PARETO DISTRIBUTION UNTUK PENGUKURAN VALUE AT RISK PADA PORTOFOLIO SAHAM SYARIAH DAN APLIKASINYA MENGGUNAKAN GUI MATLAB
}

\author{
Desi Nur Rahma ${ }^{1}$, Di Asih I Maruddani ${ }^{2}$, Tarno. ${ }^{3}$ \\ 1,2,3 Departemen Statistika, Fakultas Sains dan Matematika, Universitas Diponegoro \\ e-mail :maruddani@gmail.com
}

\begin{abstract}
The capital market is one of long-term investment alternative. One of the traded products is stock, including sharia stock. The risk measurement is an important thing for investor in other that can decrease investment loss. One of the popular methods now is Value at Risk (VaR). There are many financial data that have heavy tailed, because of extreme values, so Value at Risk Generalized Pareto Distribution is used for this case. This research also result a Matlab GUI programming application that can help users to measure the VaR. The purpose of this research is to analyze VaR with GPD approach with GUI Matlab for helping the computation in sharia stock. The data that is used in this case are PT XL Axiata Tbk, PT Waskita Karya (Persero) Tbk, dan PT Charoen Pokphand Indonesia Tbk on January, 2nd 2017 until May, 31st 2017. The results of VaRGPD are: EXCL single stock VaR 8,76\% of investment, WSKT single stock VaR 4\% of investment, CPIN single stock VaR 5,86\% of investment, 2 assets portfolio (EXCL and WSKT) 4,09\% of investment, 2 assets portfolio (EXCL and CPIN) 5,28\% of investment, 2 assets portfolio (WSKT and CPIN) 3,68\% of investment, and 3 assets portfolio (EXCL, WSKT, and CPIN) 3,75\% of investment. It can be concluded that the portfolios more and more, the risk is smaller. It is because the possibility of all stocks of the company dropped together is small.
\end{abstract}

Keywords: Generalized Pareto Distribution, Value at Risk, Graphical User Interface, sharia stock

\section{PENDAHULUAN}

Pasar modal merupakan salah satu alternatif investasi jangka panjang dan sebagai media investasi bagi pemodal. Salah satu yang diperjualbelikan pada pasar modal yaitu saham. Terdapat beberapa jenis saham, salah satunya saham syariah. Perusahaanperusahaan yang sahamnya termasuk saham syariah terdata pada Indeks Saham Syariah Indonesia (ISSI). Setiap investasi antar saham yang dilakukan akan memberikan keuntungan dan risiko yang berbeda meskipun dalam sektor industri yang sama. Harapan dari investor terhadap investasinya adalah memperoleh return sebesar-besarnya dengan risiko tertentu. Pengukuran risiko merupakan hal yang sangat penting berkaitan dengan investasi dana yang cukup besar. Oleh sebab itu, pengukuran risiko perlu dilakukan agar risiko berada dalam tingkatan yang terkendali sehingga dapat mengurangi terjadinya kerugian berinvestasi. Salah satu metode yang berkembang pesat dan sangat populer dipergunakan saat ini ialah Value at Risk (VaR) yang dipopulerkan oleh J. P. Morgan pada tahun 1994.

Data deret waktu keuangan sebagian besar memiliki ekor distribusi yang gemuk (heavy tailed) yaitu ekor distribusi turun secara lambat bila dibandingkan dengan distribusi normal. Ekor gemuk disebabkan oleh adanya nilai ekstrim. Karena adanya kasus ekstrim, maka perhitungan nilai VaR dilakukan dengan menggunakan metode Peaks Over Threshold (POT). Menurut Sari dan Sutikno (2013), metode Peaks Over Threshold (POT) adalah metode lain Extreme Value Theory (EVT) yang digunakan untuk mengidentifikasi nilai ekstrim. Metode POT menggunakan nilai patokan atau yang biasa disebut dengan threshold. Metode POT mengikuti distribusi Generalized Pareto Distribution (GPD).

Setiap investor menginginkan portofolio yang efisien (efficient portfolio), yaitu portofolio yang dapat memberikan tingkat risiko terendah dengan return ekspektasi terbesar. Salah satu metode dalam pembentukan portofolio efisien yaitu Mean Variance 
Efficient Portfolio (MVEP). Pada metode MVEP ini, portofolio efisiesn didefinisikan sebagai portofolio yang memiliki varian minimum di antara keseluruhan kemungkinan portofolio yang dapat dibentuk.

Matlab (Matrix Laboratory) adalah sebuah program untuk analisis dan komputasi numerik, merupakan suatu bahasa pemrograman matematika lanjutan yang dibentuk dengan dasar pemikiran menggunakan sifat dan bentuk matriks (Pusadan, 2014). Graphical User Interface (GUI) dapat dibuat menggunakan Matlab, yang mengandung menu, tombol, teks, grafis, dll, sehingga pengguna dapat mengubahnya secara interaktif dengan menggunakan mouse dan keyboard (Hunt, dkk, 2001). Aplikasi GUI pada Matlab diharapkan dapat mempermudah pengguna dalam perhitungan nilai $\mathrm{VaR}$.

Berdasarkan uraian tersebut, peneliti mengambil topik mengenai "Generalized Pareto Distribution Untuk Pengukuran Value at Risk pada Portofolio Saham Syariah dan Aplikasinya Menggunakan GUI Matlab".

\section{TINJAUANPUSTAKA}

\subsection{Saham Syariah}

Menurut Sunariyah (2003), saham adalah penyertaan modal dalam pemilikan suatu Perseroan Terbatas (PT) atau yang biasa disebut emiten. Suatu saham dapat dikategorikan sebagai saham syariah jika saham tersebut diterbitkan oleh: (ojk.go.id)

1. Emiten dan perusahaan publik yang secara jelas menyatakan dalam anggaran dasarnya bahwa kegiatan usaha emiten dan perusahaan publik tidak bertentangan dengan prinsip-prinsip syariah.

2. Emiten dan perusahaan publik yang tidak menyatakan dalam anggaran dasarnya bahwa kegiatan usaha emiten dan perusahaan publik tidak bertentangan dengan prinsip-prinsip syariah, namun memenuhi kriteria.

\subsection{Indeks Saham Syariah Indonesia}

Indeks Saham Syariah Indonesia (ISSI) merupakan indeks saham yang mencerminkan keseluruhan saham syariah yang tercatat di Bursa Efek Indonesia (BEI). Konstituen ISSI adalah keseluruhan saham syariah tercatat di BEI dan terdaftar dalam Daftar Efek Syariah (DES). Konstituen ISSI direview setiap 6 bulan sekali (Mei dan November) dan dipublikasikan pada awal bulan berikutnya. Konstituen ISSI juga dilakukan penyesuaian apabila ada saham syariah yang baru tercatat atau dihapuskan dari DES. (idx.co.id)

\subsection{Return}

Menurut Ghozali (2007), return adalah pendapatan yang akan diterima jika menginvestasikan uang pada suatu aktiva financial (saham, obligasi, dll) atau aktiva riil (property, tanah, dll).

$$
r=\operatorname{Ln}\left[\frac{H_{t}}{H_{t-1}}\right]
$$

Keterangan:

$\mathrm{H}_{\mathrm{t}} \quad$ = Harga saham pada periode $\mathrm{t}$

$\mathrm{H}_{\mathrm{t}-1} \quad=$ Harga saham pada periode $\mathrm{t}-1$

\subsection{Metode Mean Variance Efficient Portfolio}

Menurut Maruddani dan Purbowati (2009), salah satu metode dalam pembentukan portofolio efisien yaitu Mean Variance Efficient Portfolio (MVEP). MVEP didefinisikan sebagai portofolio yang memiliki varian minimum di antara keseluruhan kemungkinan 
portofolio yang dapat dibentuk. Jika diasumsikan preferensi investor terhadap risiko adalah risk averse (menghindari risiko), maka portofolio yang memiliki mean variance efisien (Mean Variance Efficient Portfolio) adalah portofolio yang memiliki varian minimum dari mean returnnya. Hal tersebut sama dengan mengoptimalisasi bobot $\boldsymbol{w}=$ $\left[w_{1} \ldots w_{N}\right]^{T}$ berdasarkan maksimum mean return dari varian yang diberikan.

Secara lebih formal, akan dicari vektor pembobotan w agar portofolio yang dibentuk mempunyai varian yang minimum berdasarkan dua batasan (constraints) yaitu

1. Spesifikasi awal dari return mean $\mu_{\mathrm{p}}$ harus tercapai yaitu $\mathbf{w}^{\mathrm{T}} \boldsymbol{\mu}$.

2. Jumlah proporsi dari portofolio yang terbentuk sama dengan 1 yaitu $\mathbf{w}^{\mathrm{T}} \mathbf{1}_{\mathrm{N}}=1$, dengan $\mathbf{1}_{\mathrm{N}}$ adalah vektor satu dengan dimensi $\mathrm{N}$ x 1 .

Permasalahan optimalisasi dapat diselesaikan dengan fungsi Lagrange yaitu

$$
L=\boldsymbol{w}^{T} \boldsymbol{\Sigma} \boldsymbol{w}+\lambda_{1}\left(\mu_{p}-\boldsymbol{w}^{T} \boldsymbol{\mu}\right)+\lambda_{2}\left(1-\boldsymbol{w}^{T} \mathbf{1}_{N}\right)
$$

dengan $\mathrm{L}=$ fungsi Lagrange

$\lambda=$ faktor pengali Lagrange

Untuk kasus portofolio dengan varian efisien, tidak ada pembatasan pada mean portofolio $\left(\lambda_{1}=0\right)$, sehingga pembobotan pada MVEP dengan return $\boldsymbol{X} \sim N_{N}(\boldsymbol{\mu}, \boldsymbol{\Sigma})$ adalah

$$
\boldsymbol{w}=\frac{\boldsymbol{\Sigma}^{-1} \mathbf{1}_{N}}{\mathbf{1}_{N}{ }^{2} \boldsymbol{\Sigma}^{-1} \mathbf{1}_{N}}
$$

dengan $\Sigma^{-1}=$ invers matriks varian-kovarian

\subsection{Kurtosis}

Menurut Surya dan Situngkir (2006), kurtosis merupakan ukuran kecenderungan data berada di luar distribusi. Kurtosis dari distribusi normal adalah 3, artinya jika kurtosis lebih besar dari 3 maka sampel data cenderung untuk di luar distribusi normal sedangkan jika kurtosis lebih kecil dari 3, sampel data cenderung berada di dalam lingkupan distribusi normal. Kurtosis didefinisikan sebagai:

$$
\gamma_{2}=\frac{\mu_{4}}{\sigma^{4}}
$$

dengan $\mu_{4}=E\left\{(X-\mu)^{4}\right\}$ merupakan momen tengah keempat. Distribusi yang leptokurtis (kelebihan kurtosis) ditandai dengan nilai maksimum yang sempit namun sangat besar nilainya, dan ekor distribusi yang lebih gemuk daripada ekor distribusi Gaussian. Kelebihan kurtosis dinyatakan sebagai

$$
\gamma_{2}{ }^{\prime}=\gamma_{2}-3
$$

karena kurtosis dari distribusi normal adalah 3.

\subsection{Nilai Threshold}

Menurut Sari dan Sutikno (2013), nilai threshold adalah batas ambang patokan dalam menentukan nilai ekstrim. Nilai-nilai yang berada di atas threshold merupakan nilai ekstrim. Metode dalam menentukan nilai threshold yang lebih mudah digunakan adalah metode prosentase. Menurut Chaves-Dermoulin dan Embrechts (2002), 10\% dari data merupakan nilai kelebihan atau yang disebut dengan nilai ekstrim. Langkah-langkah metode prosentase sebagai berikut:

1. Mengurutkan data dari yang terbesar hingga yang terkecil.

2. Menghitung jumlah data ekstrim $\mathrm{n}=10 \% \times \mathrm{N}$ dengan $\mathrm{n}$ adalah jumlah data ekstrim dan $\mathrm{N}$ adalah jumlah sampel data. Sehingga data yang berada di urutan 1 hingga $\mathrm{n}$ merupakan nilai ekstrim.

3. Menentukan nilai threshold $(\mathrm{u})$ yaitu data ke $(n+1)$. 


\subsection{Metode Peaks Over Threshold}

Menurut Sari dan Sutikno (2013), metode Peaks Over Threshold (POT) adalah metode lain Extreme Value Theory (EVT) yang digunakan untuk mengidentifikasi nilai ekstrim. Metode POT menggunakan nilai patokan atau yang biasa disebut dengan threshold. Metode POT mengikuti distribusi Generalized Pareto Distribution (GPD). Teorema Pickland-Dalkema dan de Haan menyatakan bahwa apabila semakin tinggi nilai threshold maka distribusinya akan mengikuti GPD.

\subsection{Generalized Pareto Distribution}

Probability Density Function GPD adalah sebagai berikut (Sari dan Sutikno, 2013):

$$
f(x \mid \xi, \sigma)=\left\{\begin{array}{r}
\frac{1}{\sigma}\left(1+\frac{\xi x}{\sigma}\right)^{-\frac{1}{\xi}-1}, \xi \neq 0 \\
\frac{1}{\sigma} \exp \left(-\frac{x}{\sigma}\right), \xi=0
\end{array}\right.
$$

dengan $0 \leq \mathrm{x}<\infty$ jika $\xi \geq 0$ dan $0 \leq \mathrm{x}<-\sigma / \xi$ jika $\xi<0$.

GPD memiliki dua parameter yaitu parameter bentuk $(\xi)$ dan parameter skala $(\sigma)$. Terdapat tiga tipe distribusi dalam GPD. Tipe 1 berdistribusi Eksponensial jika $\xi=0$, tipe 2 berdistribusi Pareto jika $\xi>0$, dan tipe 3 berdistribusi Beta jika $\xi<0$. Semakin besar nilai $\xi$ maka distribusi akan memiliki ekor yang semakin gemuk.

\subsection{Estimasi Parameter}

Menurut Sari dan Sutikno (2013), salah satu metode mengestimasi parameter Generalized Pareto Distribution (GPD) adalah Maximum Likelihood Estimation (MLE). $\mathrm{X}_{1}, \mathrm{X}_{2}, \ldots, \mathrm{X}_{\mathrm{n}}$ adalah variable random yang berdistribusi identik dan independen $\operatorname{GPD}(\xi, \sigma)$. Cara kerja metode ini adalah memaksimumkan fungsi likelihood yang merupakan fungsi peluang bersama $\mathrm{x}_{1}, \mathrm{x}_{2}, \ldots, \mathrm{x}_{\mathrm{n}}$.

Fungsi likelihood dari probability density GPD untuk $\xi \neq 0$ adalah sebagai berikut:

$$
L\left(\xi, \sigma \mid x_{1}, x_{2}, \ldots, x_{n}\right)=\sigma^{-n} \prod_{i=1}^{n}\left(1+\frac{\xi x_{i}}{\sigma}\right)^{-\left(\frac{1}{\xi}+1\right)}
$$

Fungsi ln likelihood dari persamaan (6) adalah sebagai berikut:

$$
\ln L\left(\xi, \sigma \mid x_{1}, x_{2}, \ldots, x_{n}\right)=-n \ln \sigma-\left(\frac{1}{\xi}+1\right) \sum_{i=1}^{n} \ln \left(1+\frac{\xi x_{i}}{\sigma}\right)
$$

Setelah mendapatkan fungsi ln likelihood, mendapatkan turunan pertama terhadap parameternya yaitu $\xi$ dan $\sigma$ :

$$
\begin{array}{r}
\frac{\partial \ln L}{\partial \xi}=\frac{1}{\xi^{2}} \sum_{i=1}^{n} \ln \left(1+\frac{\xi x_{i}}{\sigma}\right)-\left(\frac{1}{\xi}+1\right) \sum_{i=1}^{n} \frac{x_{i}}{\left(\sigma+\xi x_{i}\right)} \\
\frac{\partial \ln L}{\partial \sigma}=\sigma^{-1}\left(-n+(1+\xi) \sum_{i=1}^{n} \frac{x_{i}}{\sigma+\xi x_{i}}\right)
\end{array}
$$

Selanjutnya membuat persamaan turunan pertama menjadisama dengan nol hingga terbentuk persamaan yang closed form untuk mendapatkan estimasi parameter sebagai berikut:

$$
\begin{aligned}
& \hat{\xi}=\frac{\sum_{i=1}^{n} \ln \left(1+\frac{\hat{\xi} x_{i}}{\hat{\sigma}}\right)}{(1+\hat{\xi}) \sum_{i=1}^{n} \frac{x_{i}}{\left(\hat{\sigma}+\hat{\xi} x_{i}\right)}} \\
& \hat{\sigma}=\frac{(1+\hat{\xi}-n \hat{\xi}) \sum_{i=1}^{n} x_{i}}{n^{2}}
\end{aligned}
$$

Persamaan (11) merupakan persamaan yang tidak closed form karena masih terdapat parameter di dalam persamaan akhirnya. Salah satu penyelesaian persamaan yang tidak closed form adalah metode Newton Raphson.

Penggunaan metode Newton Raphson dilakukan dengan melakukan iterasi-iterasi hingga didapatkan hasil yang konvergen. Persamaan umum Newton Raphson sebagai berikut: 


$$
\theta_{l+1}=\theta_{l}-g\left(\theta_{l}\right) H^{-1}\left(\theta_{l}\right)
$$

$\mathrm{g}(\theta)$ adalah vektor gradien berukuran $1 \times \mathrm{p}$ dengan $\mathrm{p}$ adalah jumlah parameter. $\mathrm{g}(\theta)$ berisi turunan pertama probability density function GPD terhadap parameternya. $\mathrm{H}(\theta)$ adalah matriks Hessian berukuran $\mathrm{p}$ x $\mathrm{p}$ yang berisi turunan kedua terhadap parameter.

$$
\begin{aligned}
& g(\theta)=\left[\begin{array}{ll}
\frac{\partial \ln L}{\partial \xi} & \frac{\partial \ln L}{\partial \sigma}
\end{array}\right] \\
& H(\theta)=\left[\begin{array}{ll}
\frac{\partial^{2} \ln L}{\partial \xi^{2}} & \frac{\partial^{2} \ln L}{\partial \xi \partial \sigma} \\
\frac{\partial^{2} \ln L}{\partial \xi \partial \sigma} & \frac{\partial^{2} \ln L}{\partial \sigma^{2}}
\end{array}\right]
\end{aligned}
$$

Turunan kedua dari fungsi ln likelihood sebagai berikut:

$$
\begin{gathered}
\frac{\partial^{2} \ln L}{\partial \xi^{2}}=2 \xi^{-3}\left[\xi \sum_{i=1}^{n} \frac{x_{i}}{\sigma+\xi x_{i}}-\sum_{i=1}^{n} \ln \left(1+\frac{\xi x_{i}}{\sigma}\right)+\left(1+\frac{1}{\xi}\right) \sum_{i=1}^{n} \frac{x_{i}{ }^{2}}{\left(\sigma+\xi x_{i}\right)^{2}}\right] \\
\frac{\partial^{2} \ln L}{\partial \sigma^{2}}=\sigma^{-2}\left[n-(1+\xi) \sum_{i=1}^{n} \frac{x_{i}\left(2 \sigma+\xi x_{i}\right)}{\left(\sigma+\xi x_{i}\right)^{2}}\right] \\
\frac{\partial^{2} \ln L}{\partial \xi \partial \sigma}=\xi^{-1}\left[(1+\xi) \sum_{i=1}^{n} \frac{x_{i}}{\left(\sigma+\xi x_{i}\right)^{2}}-\sigma^{-1} \sum_{i=1}^{n} \frac{x_{i}}{\sigma+\xi x_{i}}\right]
\end{gathered}
$$

Iterasi Newton Raphson diawali dengan menentukan nilai $\theta_{0} . \theta_{0}$ merupakan vektor yang elemennya berisi $\hat{\xi}_{0}$ dan $\hat{\theta}_{0}$. Maka nilai estimasi awal tersebut disubstitusikan pada vektor gradien dan matriks Hessian. Nilai $\hat{\sigma}_{0}$ didekati dengan standar deviasi data ekstrim (s) sedangkan $\hat{\xi}_{0}$ didapatkan dari substitusi persamaan (12) untuk $\sigma$ ke persamaan (9). Hasil substitusi dijadikan sama dengan nol. Estimasi awal parameter bentuk sebagai berikut:

Iterasi berhenti apabila $\left|\theta_{\mathrm{n}+1}-\theta_{\mathrm{n}}\right|<\varepsilon$.

$$
\hat{\xi}_{0}=\frac{n^{2} s-\sum_{i=1}^{n} x_{i}}{\sum_{i=1}^{n} x_{i}-n \sum_{i=1}^{n} x_{i}}
$$
berikut:

Fungsi likelihood untuk $\xi=0$ dari probability density function GPD adalah sebagai

$$
L\left(\sigma \mid x_{1}, x_{2}, \ldots, x_{n}\right)=\sigma^{-n} e^{-\sum_{i=1}^{n} \frac{x_{i}}{\sigma}}
$$

Fungsi ln likelihood dari persamaan 18 adalah sebagai berikut:

$$
\ln L\left(\sigma \mid x_{1}, x_{2}, \ldots, x_{n}\right)=-n \ln \sigma-\frac{1}{\sigma} \sum_{i=1}^{n} x_{i}
$$

Estimasi parameter skala $\hat{\sigma}$ diperoleh dengan membuat persamaan turunan pertama fungsi ln likelihood menjadi sama dengan nol.

\subsection{Value at Risk}

$$
\hat{\sigma}=\bar{x}
$$

Menurut Jorion (2001), Value at Risk (VaR) merupakan kerugian maksimum yang akan diperoleh pada tingkat kepercayaan tertentu.

$$
V a R_{G P D}=u+\frac{\sigma}{\xi}\left\{\left[\frac{n}{N_{u}}(1-c l)\right]^{-\xi}-1\right\}
$$

dengan $\mathrm{cl}$ adalah tingkat kepercayaan (confidence level) VaR.

\subsection{GUI}

Menurut Pusadan (2014), Matlab (Matrix Laboratory) adalah sebuah program untuk analisis dan komputasi numerik, merupakan suatu bahasa pemrograman matematika lanjutan yang dibentuk dengan dasar pemikiran menggunakan sifat dan bentuk matriks. Menurut Hunt, dkk (2001), dengan menggunakan Matlab, Graphical User Interface (GUI) dapat dibuat, yang mengandung menu, tombol, teks, grafis, dll, sehingga pengguna dapat mengubahnya secara interaktif dengan menggunakan mouse dan keyboard. 


\section{METODE PENELITIAN}

\subsection{Jenis dan Sumber Data}

Pada penelitian ini jenis data yang digunakan adalah data sekunder. Data ini merupakan data harga penutupan (closing price) saham syariah harian pada PT XL Axiata Tbk, PT Waskita Karya (Persero) Tbk, dan PT Charoen Pokphand Indonesia Tbk periode 2 Januari 2017 sampai 31 Mei 2017 dengan jumlah data sebanyak 102. Data closing price ini didapatkan dari website www.finance.yahoo.com. Perusahan-perusahaan tersebut berasal dari sektor-sektor yang berbeda yaitu telekomunikasi, konstruksi, dan pangan.

\subsection{Metode Pengumpulan Data}

Pengambilan data dilakukan dengan mengunduh data melalui situs www.yahoo.finance.com pada perusahaan PT XL Axiata Tbk, PT Waskita Karya (Persero) Tbk, dan PT Charoen Pokphand Indonesia Tbk periode 2 Januari 2017 sampai 31 Mei 2017.

\subsection{Variabel Penelitian}

Variabel yang digunakan dalam penelitian ini adalah closing price saham harian pada PT XL Axiata Tbk, PT Waskita Karya (Persero) Tbk, dan PT Charoen Pokphand Indonesia Tbk. Pemilihan perusahaan-perusahaan tersebut berdasarkan sektor-sektor yang berbeda yaitu telekomunikasi, konstruksi, dan pangan.

\subsection{Langkah Analisis}

\section{Saham tunggal}

1. Menyiapkan data yang digunakan dalam penelitian.

2. Identifikasi pola pergerakan closing price saham.

3. Menghitung return dan membuat plotnya.

4. Menguji apakah terdapat data ekstrim dengan melihat nilai kurtosisnya.

5. Menentukan nilai threshold dan nilai-nilai ekstrim.

6. Memeriksa kesesuaian distribusi GPD nilai-nilai ekstrim menggunakan pengujian hipotesis Kolmogorov-Smirnov.

7. Mengestimasi parameter GPD dengan metode Maximum Likelihood Estimation (MLE).

8. Menghitung nilai VaR GPD.

9. Membuat Graphical User Interface (GUI) untuk perhitungan VaR GPD.

\section{Saham portofolio}

1. Menyiapkan data yang digunakan dalam penelitian.

2. Identifikasi pola pergerakan closing price masing-masing saham.

3. Menghitung return masing-masing saham dan membuat plotnya.

4. Menguji normalitas multivariat kedua return saham.

5. Menghitung portofolio dengan menggunakan metode Mean Variance Efficient Portfolio (MVEP).

6. Menguji apakah terdapat data ekstrim dengan melihat nilai kurtosisnya.

7. Menentukan nilai threshold dan nilai-nilai ekstrim.

8. Memeriksa kesesuaian distribusi GPD nilai-nilai ekstrim menggunakan pengujian hipotesis Kolmogorov-Smirnov.

9. Mengestimasi parameter GPD dengan metode Maximum Likelihood Estimation (MLE).

10. Menghitung nilai VaR GPD.

11. Membuat Graphical User Interface (GUI) untuk perhitungan VaR GPD 


\section{HASIL DAN PEMBAHASAN \\ 4.1 Pengukuran Value at Risk}

\section{Return Saham}

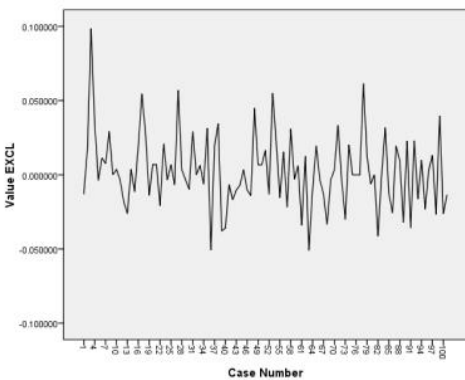

(a)

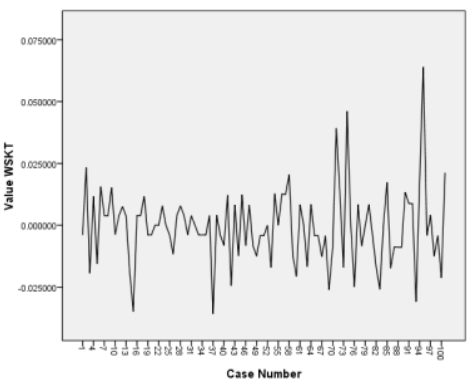

(b)

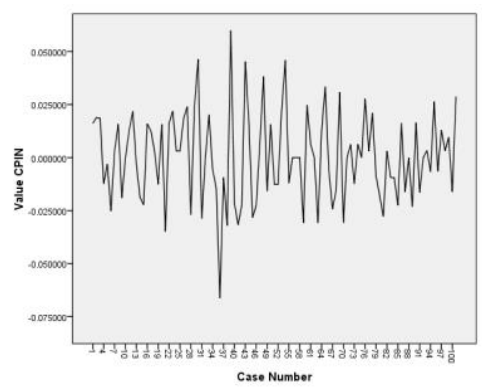

(c)

Gambar 1. Plot Return Saham: (a) EXCL, (b) WSKT, (c) CPIN;

Periode 2 Januari 2017 - 31 Mei 2017

Berdasarkan plot-plot pada Gambar 1 terlihat bahwa terdapat puncak-puncak yang berpeluang terdapat data ekstrim tetapi volatilitas cenderung tidak tinggi. Karena adanya data ekstrim, maka analisisnya bisa digunakan analisis untuk kasus Extreme Value, dengan salah satu metodenya yaitu Peaks Over Threshold menggunakan pendekatan Generalized Pareto Distribution.

\section{Asumsi Normalitas Multivariat}

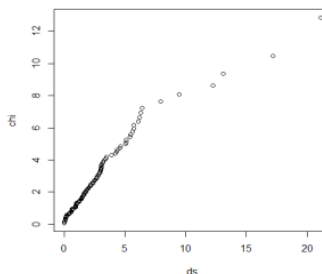

(a)

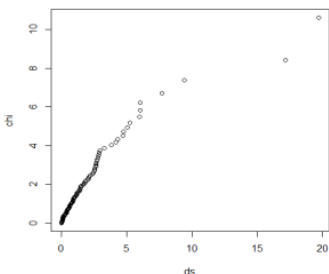

(b)

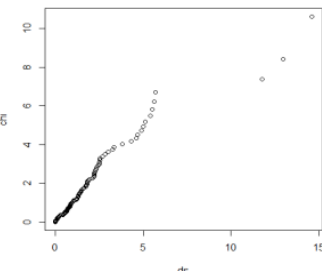

(c)

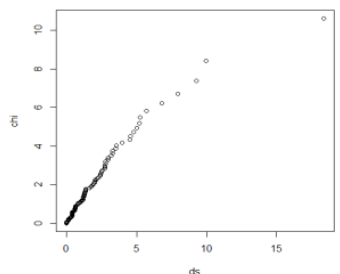

(d)

Gambar 2. Plot Uji Asumsi Normalitas Multivariat: (a) EXCL, WSKT, dan CPIN, (b) EXCL dan WSKT, (c) EXCL dan CPIN, (d) WSKT dan CPIN

Plot pada Gambar 2 merupakan plot antara jarak mahalanobis dengan nilai chi kuadrat. Data dikatakan berdistribusi normal multivariat jika plotnya membentuk garis lurus. Berdasarkan Gambar 2, dapat disimpulkan bahwa data-data tersebut berdistribusi normalitas multivariat, sehingga dapat dilanjutkan dengan metode Mean Variance Efficient Portfolio (MVEP) untuk pembentukan portofolio.

Metode Mean Variance Efficient Portofolio (MVEP)

Tabel 1. Bobot Portofolio

\begin{tabular}{|l|c|c|c|}
\hline & EXCL & WSKT & CPIN \\
\hline EXCL dan WSKT & 0,2514 & 0,7486 & \\
\hline EXCL dan CPIN & 0,3988 & & 0,6012 \\
\hline WSKT dan CPIN & & 0,6748 & 0,3252 \\
\hline EXCL, WSKT, dan CPIN & 0,1587 & 0,5886 & 0,2527 \\
\hline
\end{tabular}


Untuk portofolio 2 aset (EXCL dan WSKT), proporsi bobotnya adalah 0,318 untuk EXCL dan 0,682 untuk WSKT. Begitu pula seterusnya. Tabel return portofolio ditampilkan dalam lampiran.

\section{Kurtosis}

Tabel 2. Nilai Kurtosis

\begin{tabular}{|l|r|}
\hline & Kurtosis \\
\hline EXCL & 4,3527 \\
\hline WSKT & 5,8833 \\
\hline CPIN & 3,1815 \\
\hline EXCL dan WSKT & 3,6881 \\
\hline EXCL dan CPIN & 3,7171 \\
\hline WSKT dan CPIN & 4,8218 \\
\hline EXCL, WSKT, dan CPIN & 3,5907 \\
\hline
\end{tabular}

Berdasarkan Tabel 2, dapat disimpulkan bahwa semua data return baik data return saham tunggal maupun portofolio memiliki data-data ekstrim karena nilai kurtosis $>3$.

\section{Nilai Threshold dan Data Ekstrim}

Tabel 3. Nilai Threshold

\begin{tabular}{|l|r|}
\hline & Threshold \\
\hline EXCL & 0,031449 \\
\hline WSKT & 0,012793 \\
\hline CPIN & 0,024000 \\
\hline EXCL dan WSKT & 0,015100 \\
\hline EXCL dan CPIN & 0,021500 \\
\hline WSKT dan CPIN & 0,012400 \\
\hline EXCL, WSKT, dan CPIN & 0,013400 \\
\hline
\end{tabular}

Tabel 4. Nilai-Nilai Ekstrim

\begin{tabular}{|r|c|c|c|c|c|c|c|}
\hline No & EXCL & WSKT & CPIN & $\begin{array}{c}\text { EXCL } \\
\text { dan } \\
\text { WSKT }\end{array}$ & $\begin{array}{c}\text { EXCL } \\
\text { dan } \\
\text { CPIN }\end{array}$ & $\begin{array}{c}\text { WSKT } \\
\text { dan } \\
\text { CPIN }\end{array}$ & $\begin{array}{c}\text { EXCL, } \\
\text { WSKT, } \\
\text { dan } \\
\text { CPIN }\end{array}$ \\
\hline 1 & 0,098440 & 0,063988 & 0,059900 & 0,042100 & 0,050400 & 0,051800 & 0,040700 \\
\hline 2 & 0,061409 & 0,046130 & 0,046400 & 0,039600 & 0,040900 & 0,033200 & 0,032000 \\
\hline 3 & 0,056967 & 0,039221 & 0,045900 & 0,037800 & 0,037100 & 0,026500 & 0,028400 \\
\hline 4 & 0,054941 & 0,023347 & 0,045200 & 0,023100 & 0,037100 & 0,023700 & 0,022600 \\
\hline 5 & 0,054460 & 0,021232 & 0,038200 & 0,021900 & 0,036300 & 0,023600 & 0,021300 \\
\hline 6 & 0,044913 & 0,020451 & 0,033400 & 0,017400 & 0,035300 & 0,021900 & 0,017600 \\
\hline 7 & 0,039740 & 0,017778 & 0,030800 & 0,017300 & 0,029300 & 0,020300 & 0,017400 \\
\hline 8 & 0,034552 & 0,017316 & 0,028800 & 0,016600 & 0,027900 & 0,016800 & 0,017000 \\
\hline 9 & 0,034540 & 0,015625 & 0,027700 & 0,015800 & 0,024000 & 0,014400 & 0,015600 \\
\hline 10 & 0,033448 & 0,015267 & 0,026400 & 0,015800 & 0,023100 & 0,013800 & 0,014600 \\
\hline 11 & 0,031952 & 0,013363 & 0,024700 & 0,015700 & 0,021600 & 0,012500 & 0,014100 \\
\hline
\end{tabular}




\section{Uji Kesesuaian Distribusi Generalized Pareto Distribution (GPD)}

Tabel 5. Uji Kesesuaian Distribusi GPD

\begin{tabular}{|l|l|l|}
\hline & Dhitung & $\mathbf{D}_{\mathbf{1} \boldsymbol{\alpha}}$ \\
\hline EXCL & 0,172 & 0,391 \\
\hline WSKT & 0,148 & 0,391 \\
\hline CPIN & 0,139 & 0,391 \\
\hline WEXCL dan WSKT & 0,218 & 0,391 \\
\hline EXCL dan CPIN & 0,154 & 0,391 \\
\hline WSKT dan CPIN & 0,163 & 0,391 \\
\hline EXCL, WSKT, dan CPIN & 0,121 & 0,391 \\
\hline
\end{tabular}

Dapat disimpulkan bahwa data-data ekstrim semua return saham tunggal dan portofolio mengikuti distribusi Generalized Pareto Distribution karena semua $\mathrm{D}_{\text {hitung }}<\mathrm{D}_{1-\alpha}(0.391)$.

\section{Estimasi Parameter Generalized Pareto Distribution (GPD)}

Tabel 6. Estimasi Parameter GPD

\begin{tabular}{|l|c|c|}
\hline & $\xi$ & $\boldsymbol{\sigma}$ \\
\hline EXCL & $-1,0860$ & 0,1069 \\
\hline WSKT & $-0,6487$ & 0,0445 \\
\hline CPIN & $-1,1082$ & 0,0664 \\
\hline EXCL dan WSKT & $-1,2167$ & 0,0512 \\
\hline EXCL dan CPIN & $-1,2466$ & 0,0628 \\
\hline WSKT dan CPIN & $-0,7820$ & 0,0418 \\
\hline EXCL, WSKT, dan CPIN & $-1,1553$ & 0,0470 \\
\hline
\end{tabular}

Value at Risk (VaR) Generalized Pareto Distribution (GPD)

Tabel 7. Nilai Value at Risk (VaR)

\begin{tabular}{|l|l|}
\hline & VaR \\
\hline EXCL & 0,0876 \\
\hline WSKT & 0,0400 \\
\hline CPIN & 0,0586 \\
\hline EXCL dan WSKT & 0,0409 \\
\hline EXCL dan CPIN & 0,0528 \\
\hline WSKT dan CPIN & 0,0368 \\
\hline EXCL, WSKT, dan CPIN & 0,0375 \\
\hline
\end{tabular}

Berdasarkan nilai-nilai pada Tabel 7, terlihat bahwa risiko terkecil adalah portofolio saham 2 aset yang terdiri dari saham PT Waskita Karya (Persero) Tbk dan PT Charoen Pokphand Indonesia Tbk. Portofolio saham 3 aset juga memiliki nilai Value at Risk yang kecil, karena biasanya semakin banyak jumlah perusahaan pada portofolionya maka semakin kecil risikonya, karena kemungkinan anjloknya semua saham-saham perusahaan tersebut secara bersama-sama kecil. 


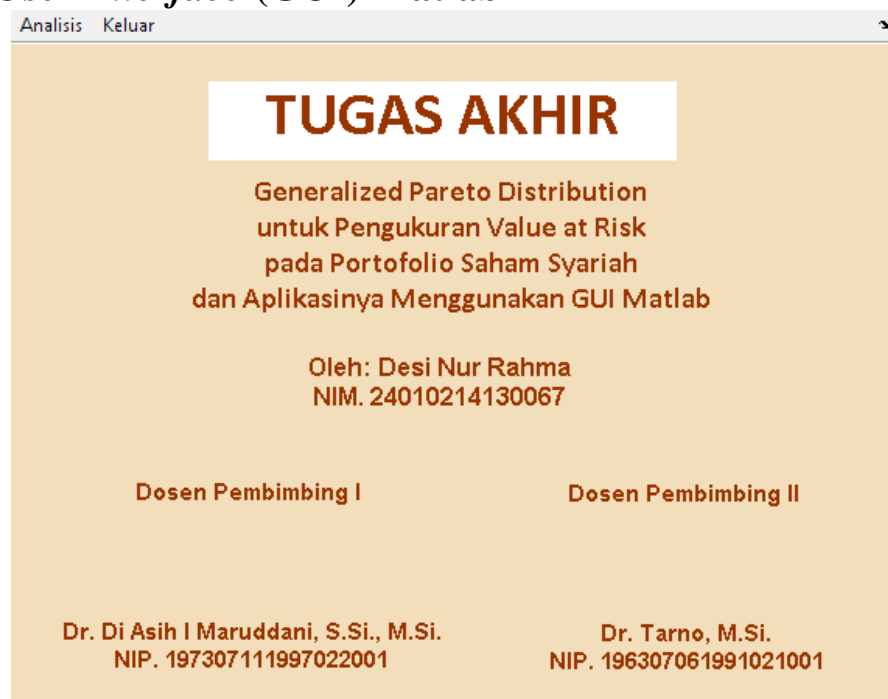

Gambar 3. Tampilan Home GUI Matlab Generalized Pareto Distribution untuk Pengukuran Value at Risk

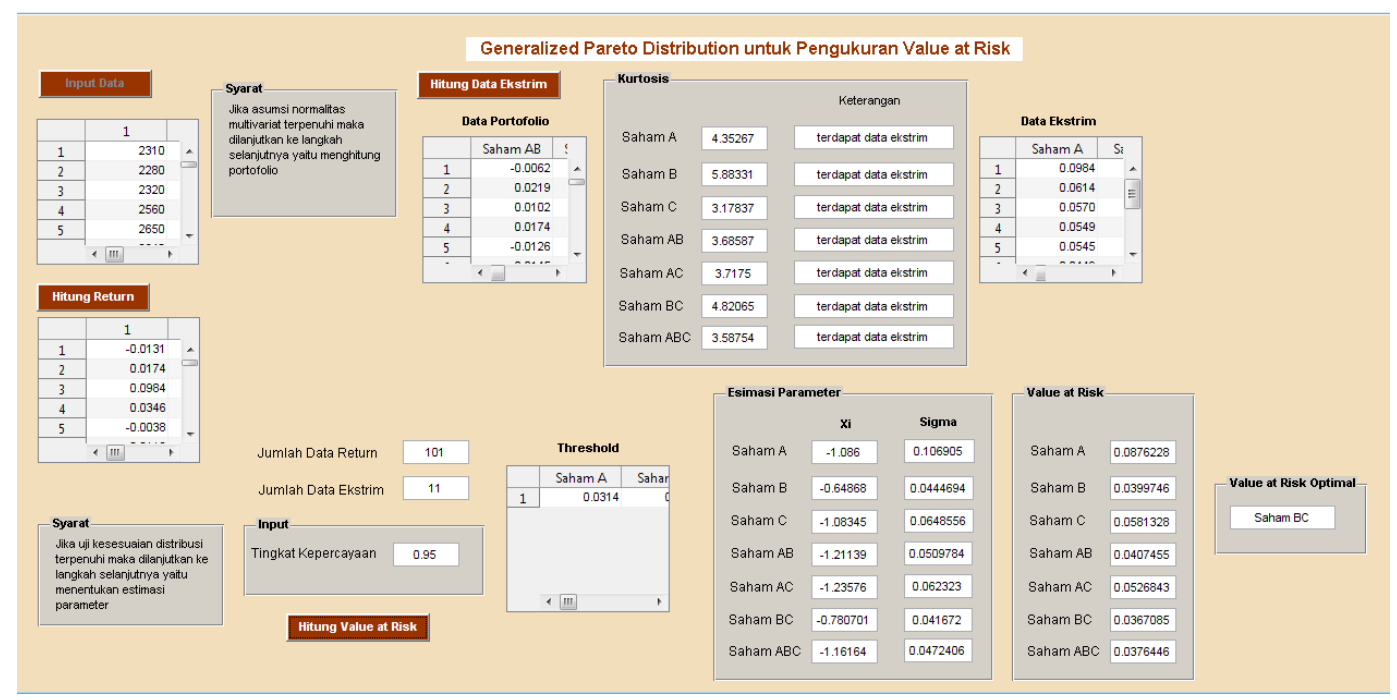

Gambar 4. Tampilan Analisis

Pemaparan tampilan dan cara penggunaan program GUI Matlab Generalized Pareto Distribution untuk Pengukuran Value at Risk sebagai berikut.

1. Tampilan Home GUI Matlab Generalized Pareto Distribution untuk Pengukuran Value at Risk dapat dilihat pada Gambar 3.

2. Bagian dalam GUI Matlab Generalized Pareto Distribution untuk Pengukuran Value at Risk dapat ditampilkan dengan melakukan klik pada tombol "Analisis", sehingga akan muncul tampilan seperti pada Gambar 4.

3. Penginputan data dilakukan dengan mengklik tombol "Input Data". Data yang dimasukkan adalah data closing price saham. Data tersebut akan muncul di dalam tabel yang telah tersedia seperti pada Gambar 4.

4. Perhitungan nilai return dilakukan dengan mengklik tombol "Hitung Return". Hasil outputnya akan muncul pada tabel yang telah tersedia seperti pada Gambar 4. 
5. Jika syarat asumsi normalitas multivariat terpenuhi maka dapat dilanjutkan pada langkah selanjutnya yaitu mengklik tombol "Hitung Data Ekstrim" untuk menentukan data portofolio, kurtosis, dan data ekstrim seperti pada Gambar 4.

6. Jika syarat uji kesesuaian distribusi terpenuhi maka langkah berikutnya adalah pendugaan parameter dan perhitungan nilai Value at Risk serta penentuan Value at Risk yang paling optimal dengan memasukkan nilai tingkat kepercayaan seperti pada Gambar 4.

7. Cara mengakhiri program yaitu dengan melakukan klik pada tombol "Keluar" seperti pada Gambar 3.

\section{KESIMPULAN}

Dari hasil perhitungan, diperoleh:

1. VaR saham tunggal EXCL, WSKT, dan CPIN masing-masing sebesar 0,0876, 0,04, dan 0,0586 yang menunjukkan bahwa dengan tingkat kepercayaan $95 \%$, maka kemungkinan kerugian maksimal pada 1 hari ke depan adalah $8,76 \%, 4 \%$, dan 5,86\% dari besarnya investasi.

2. VaR portofolio 2 aset (EXCL dan WSKT), (EXCL dan CPIN), dan (WSKT dan CPIN) masing-masing sebesar 0,0409, 0,0528, dan 0,0368 yang menunjukkan bahwa dengan tingkat kepercayaan 95\%, maka kemungkinan kerugian maksimal pada 1 hari ke depan adalah 4,09\%, 5,28\%, dan 3,68\% dari besarnya investasi.

3. VaR portofolio 3 aset (EXCL, WSKT, dan CPIN) sebesar 0,0375, yang menunjukkan bahwa dengan tingkat kepercayaan 95\%, maka kemungkinan kerugian maksimal pada 1 hari ke depan adalah 3,75\% dari besarnya investasi.

Dari 7 nilai VaR yang telah diperoleh, baik saham tunggal, portofolio 2 aset, dan portofolio 3 aset, diperoleh VaR optimal adalah VaR portofolio 2 aset yaitu PT Waskita Karya (Persero) Tbk (WSKT) dan PT Charoen Pokphand Indonesia Tbk (CPIN) sebesar 0,0368. Portofolio saham 3 aset juga memiliki nilai Value at Risk yang kecil, karena biasanya semakin banyak portofolio, maka semakin kecil risikonya. Hal ini dikarenakan kemungkinan anjloknya semua saham-saham perusahaan tersebut secara bersama-sama kecil.

Pada penelitian ini juga berhasil dalam melakukan komputasi Generalized Pareto Distribution untuk Pengukuran Value at Risk dengan menggunakan GUI Matlab. Dengan GUI ini akan mempermudah pengguna dalam melakukan pengukuran Value at Risk dengan pendekatan Generalized Pareto Distribution.

\section{DAFTAR PUSTAKA}

Ahmad, K. 2004. Dasar-Dasar Manajemen Investasi dan Portofolio. Jakarta: PT Rineka Cipta.

Chaves-Dermoulin, V. dan Embrechts P. 2002. "Smooth Extermal Models for Operational Risk". Financial Valuation and Risk Management Working Paper Series. 135.

Dowd, K. 2002. An Introduction to Market Risk Measurement. England: John Wiley \& Sons.

Ghozali, I. 2007. Manajemen Risiko Perbankan: Pendekatan Kuantitatif Value at Risk (VaR). Semarang: Badan Penerbit Universitas Diponegoro.

Hanafi, M.M. 2006. Manajemen Risiko. Yogyakarta: Unit Penerbit dan Percetakan Sekolah Tinggi Ilmu Manajemen YKPN.

Haryatmi, S. dan Suryo Guritno. 2008. Metode Statistika Multivariat. Jakarta: Universitas Terbuka. 
Hunt, B.R., Ronald L. Lipsman, Jonathan M. Rosenberg, Kevin R. Coombes, John E. Osborn, dan Garret J. Stuck. 2001. A Guide to Matlab for Beginner and Experienced Users. NewYork: Cambridge University.

idx.co.id. 2018. Indonesia Sharia Stock Index (ISSI). http://www.idx.co.id/id-id/beranda/ produkdanlayanan/pasarsyariah/indekssahamsyariah.aspx. Diakses pada tanggal 7 Februari 2018.

Jorion, P. 2001. Value at Risk: The New Benchmark for Managing Financial Risk. USA: McGraw-Hill.

Maruddani, D.A.I. dan Purbowati, A. 2009. "Pengukuran Value at Risk pada Aset Tunggal dan Portofolio dengan Simulasi Monte Carlo". Media Statistika. Vol. 2 (2), 93-104.

ojk.go.id. 2018. Pasar Modal Syariah. http://www.ojk.go.id/id/kanal/syariah/ Pages/PasarModal-Syariah.aspx. Diakses pada tanggal 4 Februari 2018.

Pusadan, M.Y. 2014. Pemrograman Matlab pada Sistem Pakar Fuzzy. Yogyakarta: Deepublish.

Sari, Y.D.W. dan Sutikno. 2013. "Estimasi Parameter Generalized Pareto Distribution pada Kasus Identifikasi Perubahan Iklim di Sentra Produksi Padi”. Jurnal Sains dan Seni POMITS. Vol. 2 (2).

Sunariyah. 2003. Pengantar Pengetahuan Pasar Modal. Yogyakarta: Unit Penerbit dan Percetakan (UPP) AMP YKPN.

Surya, Y. dan Hokky Situngkir. 2006. "Value at Risk yang Memperhatikan Sifat Statistika Distribusi Return”. Munich Personal RePEc Archive Paper, 895. 